ефективності підготовки вчителів технологій в умовах входження до Європейського освітянського простору.

\title{
Література
}

1. Воронин Т.П. Образование в эпоху новых информационных технологий /Т.П. Воронин, В. П. Кашица. - М., 1995. - 443 с.

2. Завізена Н. Комп’ютеризація освіти 3 позиції психолого-педагогічного аспекту / Н. Завізена // Рідна школа. - 1999р. - №11. - С. 62.

3. Оспенникова Е. В. Современная образовательная среда и методы обучения / Е.В. Оспенникова // Школьные технологии. - 2002. - № 4. - С. 24-35.

4. Полат Е. С. Интернет в образовании / Е.С. Полат. - М., 2001. - 276 с.

5. Питюков В. Ю. Основы педагогической технологи / В.Ю. Питюков. - М., 1997. C. 6-11.

Стаття надійшла до редакції 29.05.2012 p.

УДК 537.8

В. Г. Жердєв, викладач,

В. В. Мосолов, кандидат пед. наук, доцент,

Криворізький педагогічний інститут ДВНЗ «Криворізький національний університет»

\section{ФОРМУВАННЯ ЯКІСНИХ ЗНАНЬ ТА НАВИЧОК САМОКОНТРОЛЮ СТУДЕНТІВ ТЕХНОЛОГО-ПЕДАГОГІЧНОГО ПРОФІЛЮ ВНЗ ЗА ДОПОМОГОЮ НАВЧАЛЬНИХ КОМПЛЕКСІВ ІЗ ЧПУ ТА У ПРОЦЕСІ ВИКЛАДАННЯ КУРСУ «АВТОСПРАВА»}

Жердєв В.Г., Мосолов В.В. Формування якісних знань та навичок самоконтролю студентів технолого-педагогічного профілю ВНЗ за допомогою навчальних комплексів з ЧПУ та у прочесі викладання курсу «Автосправа».

Темпи розвитку сучасного стану науково-технічного прогресу передбачають упровадження в сучасну педагогічну освіту високотехнологічних засобів підготовки педагогів. Однією з нових сучасних технологій для навчання студентів технолого-педагогічного профілю $\epsilon$ використання навчальних комплексів з числовим програмним керуванням (ЧПК), яка дозволить оптимізувати сам процес освіти та підвищити рівень професійних компетентностей студентів.

Ключові слова: комп'ютеризачія, автоматизачія, новітні технології, розширення знань та умінь студентів, система числового програмного керування (СЧПК), самоконтроль, методи самостійної роботи.

Жердев В. Г., Мосолов В. В. Формирование качественных знаний и навыков самоконтроля студентов технолого-педагогического профиля вузов при помощи учебных комплексов по ЧПУ при преподавании курса «Автодело».

Темпы развития современного состояния научно-технического прогресса предусматривают внедрение в современную педагогическое образование высокотехнологичных средств подготовки педагогов. Одной из новых современных технологий для обучения студентов технолого-педагогического профиля является использование учебных комплексов с числовым программным управлением (ЧПУ), которая позволит оптимизировать сам проиесс образования и повысить уровень профессиональных компетенций студентов.

Ключевые слова: компьютеризачия, автоматизачия, новейшие технологии, растирения знаний и умений студентов, система числового программного управления (СЧПК), самоконтроль, методы самостоятельной работы. 
Zherdev V., Mosolov V. Formation of high-quality knowledge navychek s self students technopedagogic universities through educational complexes for CNC in teaching the course

The pace of the current state of scientific - technical progress includes the introduction of modern high-tech education teacher training teachers. One of the new technologies for teaching students profile is the use of educational facilities of numerically controlled $(\mathrm{CNC})$, which will optimize the process of education and enhance professional competence of students.

Keywords: computeryuteryzatsiya, automation, new technolos, increasing knowledge and skills of the students, the system numerical control (SCHPK), self-control, methods of independent work.

Сучасний стан системи освіти у вищих педагогічних навчальних закладах потребує удосконалення типових навчальних програм та методик, засобів і комплексів для викладання низки спеціалізованих дисциплін. Першорядного значення набуває проблема використання сучасних інформаційних технологій у навчально-виховному процесі. Відбувається поступова комп'ютеризація усіх галузей вищої освіти сьогодення. У контексті освітніх євроінтеграційних процесів особливої актуальності набуває питання щодо застосування методів навчання, спрямованих на формування соціально-психологічних компетентностей студентів, 3-поміж яких чільне місце посідають інформаційно-інтелектуальні. Нині йдеться мова про інформаційні технологіі, що все активніше входять до складу педагогічної діяльності вчителів різних предметних галузей.

Дидактична доцільність використання комп'ютерних систем у навчальному процесі визначається педагогічними цілями, досягнення яких можливо тільки за допомогою комп'ютера, тобто завдяки його можливостям. Отже, виникають якісно нові дидактичні умови підготовки висококваліфікованих кадрів.

Для підготовки кадрів технолого-педагогічної спеціалізації необхідною умовою $є$ залучення у навчання новітніх технологій та устаткування. Зазвичай матеріально-технічна база не відповідає вимогам сучасного рівня технічних досягнень. Однією з альтернативних технологій, застосування якої могло б вирішити дану проблему, є використання навчальних комплексів 3 числовим програмним керуванням (ЧПК) в освітньому процесі.

Числове програмне управління (ЧПК) - комп'ютеризована система управління, що керує приводами технологічного обладнання. Для керування ЧПК використовує числові дані, що, як правило, уводяться під час виконання операції.

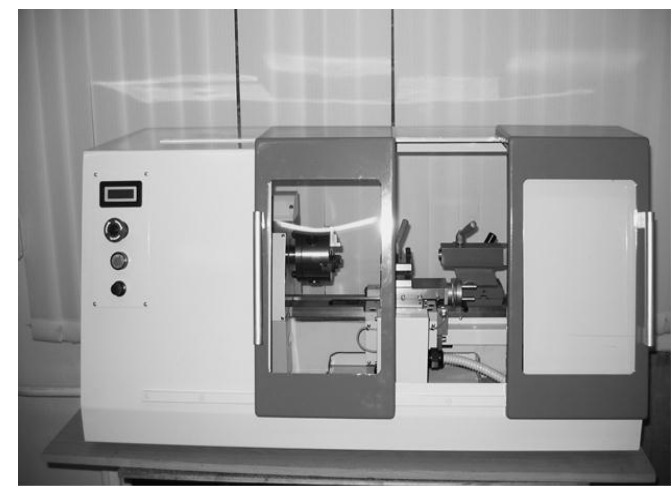

Рис. 1. Навчальний токарний станок з комп'ютерною системою ЧПК 
Обладнання з ЧПК для підготовки педагогів-технологів може бути представлено станковим парком, наприклад, станками (станки, які обладнані числовим програмним управлінням, мають назву станки з ЧПК) для оброблення металів (наприклад, фрезерувальні та токарні), дерева, пластмас; для різання листових заготовок, для обробки тиском тощо.

Використання навчальних комплексів з числовим програмним керуванням має багато переваг у застосуванні їх у навчально-виховному процесі в процесі підготовки кваліфікованих кадрів технолого-педагогічного профілю.

Станки з ЧПК є більш надійними, точними та безпечними. Виконання студентами різного типу завдань відбувається шляхом керування процесом за допомогою комп'ютерної техніки. Машина переводить внесену інформацію у числові дані і весь процес виконання заданого завдання відбувається автоматично. Максимальне підвищення умінь та навичок студентів - це уміння користуватись всіма можливостями сучасної техніки.

Використання устаткування з числовим програмним $\epsilon$ економнішим, устаткування $\epsilon$ більш компактним. Під час обладнання станкової майстерні 3 системами ЧПК пропонується залишити тільки декілька станків застарілого зразка для демонстрації будови та принципу механічної роботи машин. Але практичні та лабораторні заняття пропонується виконувати все ж на обладнані нового зразка.

Виконання практичних робіт за допомогою систем числового програмного керування студентами $є$ більш ефективним (у зв'язку 3 економією). Автоматизована система набагато швидше виконує команди та дії, які необхідно послідовно виконати. Це дозволить охопити більший обсяг навчального матеріалу та, тим самим, підвищити якість знань студентів та удосконалити їхні практичні професійні вміння та навички.

Для використання системи числового програмного керування при підготовці майбутніх педагогів-технологів, студентів попередньо необхідно ознайомити зі специфікою та системою роботи програмного забезпечення, яким оснащене устаткування. Для цього пропонується введення коротких спеціалізованих курсів на молодших курсах (I - II рік навчання). Курси мають теоретичну специфіку.

Отже, можна зробити висновок, що навчальний комплекс $з$ числовим програмним керуванням - це сучасний високотехнологічний засіб підготовки висококваліфікованих кадрів $з$ технолого-педагогічної спеціальності, який не тільки допомагає підвищити уміння та навички студентів у користуванні сучасним устаткуванням, а й дієвий «пристрій» для розвитку інтелектуальної культури та технологічних компетентностей студентів. Можна стверджувати, що розроблена технологічна система піднесе на новий та більший рівень кваліфікаційні якості педагогів-технологів.

Розглянуті питання активізації навчальної діяльності студентів у процесі вивчення автомобільних дисциплін у ВН3 за рахунок збільшеннячастки самостійної роботи студентів і підвищення вимог до самоконтролю знань і вмінь майбутніх спеціалістів. 
3 переходом до багаторівневої системи освіти суттєво скоротилась частка аудиторного навантаження. Це потребує активізації самостійної роботи студентів, i, відповідно, вміння методології викладання. Необхідно не тільки передати інформацію, а й навчити навичкам ефективної самостійної діяльності.

Процес викладання, на нашу думку, за своєю будовою повинен бути максимально наближений до логічної структури самого життя. А життя постійно ставить все нові й нові завдання (професійні, соціальні, побутові тощо), які найчастіше доводиться розв'язувати самостійно.

Спроби раціоналізації навчального процесу були здійснені нами у процесі вивчення курсів «Автомобілі» та «Експлуатація та ремонт автомобілів». Після викладення блоку лекцій, що об’єднані однією тематичною спрямованістю, більшість практичних занять проводилось у формі самостійної роботи (завдання видавались студентам у формі тестів). За необхідності, перед початком індивідуальної роботи розглядались деякі загальні моменти визначеної теми. У процесі роботи здійснювався активний контроль за виконанням завдань. Важливим моментом (особливо на початковій стадіï) є вміння вселити у кожного студента впевненість у своїх силах. Під час виконання завдання можна використовувати літературу, конспект лекцій, довідники. Процес самостійної роботи контролюється тематичним графіком. Оцінка виставляється або традиційним способом, або за рейтинговою системою. Отже, для більшості студентів відпадає необхідність в іспиті (заліку), оскільки наприкінці семестру ставиться середня оцінка за результатами виконання самостійних робіт. Екзаменуються лише ті студенти, оцінка у яких коливається між сусідніми балами, і вони бажають «дотягнути» іiї до більш високого рівня.

За такої побудови навчального процесу, який заснований на принципі саморегулювання, агітувати студента відвідувати лекції немає необхідності, він працює сам, оскільки «його доля в його руках». Він 3 більшою активністю включається в науково-дослідну роботу.

Лекції, за такого підходу, також мають бути іншими. Одним 3 найефективніших методів, на наш погляд, є виклад матеріалу за методом вільної співбесіди, у процесі якої студент може навести свій приклад, або зробити поправку у випадку неточності, яка була допущена викладачем. Звісно, професіоналізм лектора повинен бути досить високим, тобто сюжетна лінія лекції вибудовувалась на очах студентів. При цьому викладач немовби «розчиняється» у потоці слухачів, і «віз» знання витягується спільними зусиллями. У цьому випадку спрацьовує відомий афоризм Аристотеля «іншого не запалиш, якщо сам не гориш». Бажано, щоб окрім професійних навичок викладач мав ще деякі якості. Доречно навести слова професора О. Минакова, якого академік Ішлинський уважав генієм викладацької діяльності: «Щоб бути справжнім педагогом, потрібно бути вченим, філософом, артистом, вихователем та Людиною». 
Результативність навчально-пізнавальної діяльності студентів залежить не тільки від змісту, форм та методів навчання, але й самоконтролю за якістю отриманих спеціальних знань, умінь та навичок.

Традиційно у студентів сформувалось розуміння, що контроль виконує тільки викладач, і значно меншою мірою вони ознайомлені з такою формою, як самоконтроль. Тому формування у майбутніх учителів навичок самоконтролю у різних формах (перевірка самостійно виконаних робіт, розв'язання обраних практичних тестів, самостійне користування технічними приладами і методичними засобами навчання) $є$ ефективним способом розумового та морального становлення студентів.

\section{Література}

1. Каштальян И.А. Обработка на станках с числовым программным управлением / И. Каштальян, В. Клевзович. - К. : Высшая школа, 1989. - 271 с.

2. Мазеин П.Г. Виртуальные и реальные тренажеры с компьютерным управлением / П.Г. Мазеин, С.С. Панов, А.А. Беленов // Дистанционное и виртуальное обучение. - № 7. -2010 . C. $25-37$.

3. Мазеин П.Г. Развитие учебных комплексов с компьютерными системами числового программного управления / П.Г. Мазеин, С.В. Шереметьев, С.С. Панов, С.Н. Свиридов // Телекоммуникации и образование. - 2006. - №3. - С. 17-20.

4. Сосонкин В.Л. Программирование систем числового программного управления / В. Сосонкин, Г. Мартинов. - Логос, Университетская книга, 2008. - 344 с.

Стаття надійшла до редакції 30.05.2012 p.

\section{ШЛЯХИ ЕФЕКТИВНОГО ФОРМУВАННЯ ІНФОРМАЦЙНОЇ КУЛЬТУРИ МАЙБУТНІХ ІНЖЕНЕРІВ-ПЕДАГОГІВ В УМОВАХ МОДЕРНІЗАЦІЇ ВІТЧИЗНЯНОЇ ОСВІТНЬОЇ СИСТЕМИ}

\footnotetext{
Волкова Н.В. Шляхи ефективного формування інформаиійної культури майбутніх інженерів-педагогів в умовах модернізачії вітчизняної освітньої системи.

У статті розкрито шляхи ефективного формування інформаційної культури майбутніх інженерів-педагогів в умовах ВПНЗ. Доведено корелятивний взаємозв'язок між інформаиійним й технологічним аспектами формування інформаційної культури студентів у межах інформатизаиії вищої иколи. педагоги.

Ключові слова: інформачія, інформаційна культура, інформатизаиія, майбутні інженери-

Волкова Н. В. Пути эффективного формирования информащионной культуры будущих инженеров-педагогов в условиях модернизачии отечественной образовательной системьл.

В статье раскрыты пути эффективного формирования информационной культуры будущих инженеров-педагогов в условиях ВПУЗ. Доказана коррелятивная взаимосвязь между информачионным и технологическим аспектами формирования студентов информачионной культуры в рамках информатизачии высшей школье.

Ключевые слова: информация, информационная культура, информатизачия, будущие инженеры-педагоги.
} 